\title{
DRIFT VELOCITY MEASUREMENT AND HOT ELECTRON CAPTURE IN AIGaN/AIN/ GaN
}

\author{
O. Kiprijanovič, A. Matulionis, J. Liberis, and L. Ardaravičius \\ Semiconductor Physics Institute, A. Goštauto 11, LT-01108 Vilnius, Lithuania \\ E-mail: matulionis@pfi.lt
}

Received 26 August 2005

\begin{abstract}
Nanosecond technique was used to control the electron density during the electron drift velocity measurement in the absence of channel self-heating. A threshold-type hot electron capture is determined to be reducing the density of mobile electrons: the reduction up to $30 \%$ is found in the investigated range of fields below $65 \mathrm{kV} / \mathrm{cm}$ at room temperature. No change in electron density is found in the range below $25 \mathrm{kV} / \mathrm{cm}$. The corrected drift velocity data are presented.
\end{abstract}

Keywords: nitride heterostructures, hot electrons, drift velocity, two-dimensional electron gas, AlGaN/AlN/GaN

PACS: 72.20.-I; 72.20.Ht; 73.21.Fg

\section{Introduction}

Nitride heterostructures with two-dimensional electron gas (2DEG) channels support excellent highpower performance of high electron mobility transistors (HEMTs) at microwave frequencies [1-3]. The highest reported cutoff frequency exceeds $100 \mathrm{GHz}$ $[4,5]$. Its dependence on gate length, after a suitable deembedding procedure, yields the hot electron drift velocity. The obtained highest values, $\sim 1.2 \cdot 10^{7} \mathrm{~cm} / \mathrm{s}$ $[6,7]$, are several times lower than those expected from either the traditional Monte Carlo simulation [8] or the femtosecond laser time-of-flight experiments carried out on $\mathrm{GaN}$ diodes [9].

Another way for estimating the electron drift velocity is based on measuring the current along an ungated channel. In a GaN-based 2DEG channel at a high electric field, the estimated velocity is lower as compared with that in doped GaN [10]. Channel selfheating [11], electron gas degeneracy [12], accumulation of non-equilibrium optical phonons (hot phonons) $[13,14]$, interface roughness [14], AlN phonons [14], and other effects are considered among the possible causes responsible for the reduced drift velocity in a high density 2DEG channel. Despite of recent efforts to control the causes, the range of maximum reported drift velocity remains wide, $(1 \ldots 3) \cdot 10^{7} \mathrm{~cm} / \mathrm{s}$ [15-17].

The estimation of drift velocity from the current data often assumes that the electron density is independent of the applied electric field. However, impact ionisa- tion of occupied donors and capture of hot electrons into empty traps can change the density of mobile electrons in the channel. The aim of the paper is to demonstrate that a hot electron capture takes place in the undoped AlGaN/AlN/GaN channels. The estimation of the electron drift velocity is reconsidered.

\section{Experimental}

Molecular beam epitaxy grown nominally undoped $\mathrm{Al}_{0.33} \mathrm{Ga}_{0.67} \mathrm{~N} / \mathrm{AlN} / \mathrm{GaN}$ heterostructures were investigated. A $1 \mu \mathrm{m}$ thick $\mathrm{GaN}$ buffer layer was grown on a sapphire substrate, the layer was overgrown with a $1.5 \mathrm{~nm}$ layer of $\mathrm{AlN}$ and a $12 \mathrm{~nm}$ layer of $\mathrm{Al}_{0.33} \mathrm{Ga}_{0.67} \mathrm{~N}$, and the latter was covered with a $30 \mathrm{~nm}$ layer of $\mathrm{Si}_{3} \mathrm{~N}_{4}$ for protection. Spontaneous polarization and piezoelectric fields were responsible for the 2DEG formation. The electron sheet density was estimated at a low electric field: $n=1 \cdot 10^{13} \mathrm{~cm}^{-2}$.

Coplanar $\mathrm{Ti} / \mathrm{Al} / \mathrm{Ti} / \mathrm{Au}$ electrodes were formed at 1080 K. Samples for the current measurements had two ohmic electrodes each. The results are presented for the samples with $100 \times 100 \mu \mathrm{m}^{2}$ contact pads, the gap between the electrodes is $5 \mu \mathrm{m}$.

Figure 1 illustrates a schematic band diagram of an $\mathrm{AlGaN} / \mathrm{AlN} / \mathrm{GaN}$ heterostructure with a degenerate electron gas confined in the $\mathrm{GaN}$ layer. Let us assume that shallow traps are present in GaN. At equilibrium, the trap levels are occupied when located below the 


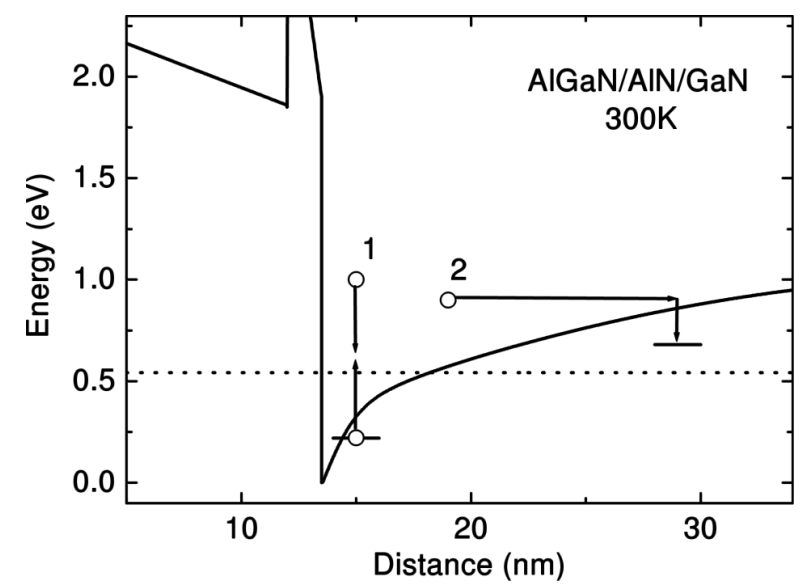

Fig. 1. A schematic band diagram for an AlGaN/AlN/GaN channel with a 2DEG. Dotted line is Fermi energy. Occupied traps contain a circle. Arrows stand for impact ionisation (1) and capture (2).

Fermi energy, but they are empty elsewhere. Under bias, the electrons are accelerated by the applied electric field, acquire excess energy, and interact with traps. Two possible processes can take place: a high energy electron can either ionise an occupied trap in the channel (Fig. 1, process 1 ) or be captured by an empty trap located at some distance from the channel (process 2). The electrons must be activated in order to take part in these processes. The electron density would increase if the impact ionisation took place. The capture would reduce the electron density.

Our goal is the experimental study of possible changes in the electron sheet density caused by the electron heating. For this purpose, we measure current at a low bias before and after a short pulse of a high voltage. The short pulse $(\sim 1.5 \mathrm{~ns})$ of voltage is generated by a charged coaxial line and a mercury-wetted relay (see pulse $p$, inset of Fig. 2). Pulse $p$ triggers a slave generator that sends a step of low voltage to the sample (step $s$ ). The pulse and step arrivals are controlled with the delay lines. The pulse heats the electrons, and the step voltage probes the sample conductance before and after the pulse. The channel self-heating due to the pulses is estimated to be negligible.

The signal is fed to the sampling oscilloscope. The channel conductance is determined at $2 \mathrm{kV} / \mathrm{cm}$ field before and after the high field pulse. When the high voltage is off, the sample mobility recovers fast enough, but the conductance returns to its initial value relatively slowly (the time constant is 150-200 ns).

Reasonable results on the low field conductance are obtained after a $5 \mathrm{~ns}$ time delay following the high voltage pulse. Such a delay is a compromise: measuring a weak signal immediately after the pulse of a high volt-

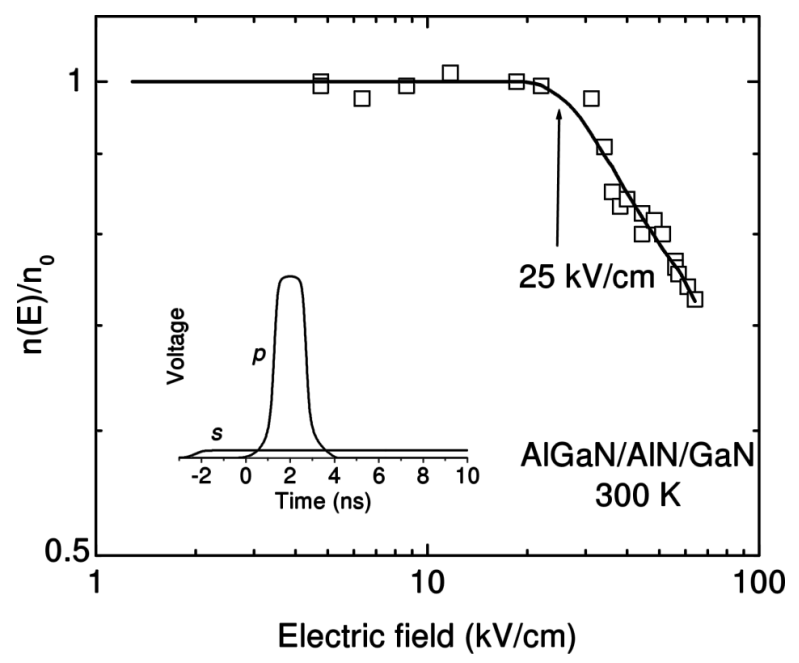

Fig. 2. Field-dependent relative electron sheet density for Al$\mathrm{GaN} / \mathrm{AlN} / \mathrm{GaN}$ at room temperature. Symbols stand for the experimental data, solid line guides the eye. Inset shows a high field pulse $(p)$ superimposed over the step of a low field $(s)$.

age is not accurate because of ripples due to a parasitic RLC circuit (pad capacitance, whisker inductance, voltage source impedance, etc.) and a piezo-acoustic wave resonance in the $\mathrm{GaN}$ layer. A longer delay is helpful. However, the delay should not be too long for obtaining data on the high-field-induced changes in the electron density.

Let $I_{B}$ and $I_{A}$ stand for the current before and after the high voltage pulse, respectively. Since the electric field during the measurement is the same, one has $n(E) / n_{0}=I_{A} / I_{B}$, where $n(E)$ is the electron sheet density at a high electric field and $n_{0}$ is the equilibrium sheet density. The inaccuracy due to the delay and the recovery makes a couple percent of the field-induced change.

\section{Experimental results and discussion}

The field-induced changes in the electron sheet density are illustrated in Fig. 2. The horizontal axis presents the peak value of the electric field applied during the short pulse. The decrease in the electron density is evident at a high bias. The threshold field is estimated to be $25 \mathrm{kV} / \mathrm{cm}$. The relaxation time of the recovery is estimated to be 150-200 ns.

Let us interpret the results in terms of hot electron capture. After Fig. 1, the hot electrons can be captured by the empty traps located in $\mathrm{GaN}$ at some distance from the channel (process 2). The results show that no capture takes place until, at $E>25 \mathrm{kV} / \mathrm{cm}$, the electron temperature becomes high enough (over $1000 \mathrm{~K}$ [18]). 


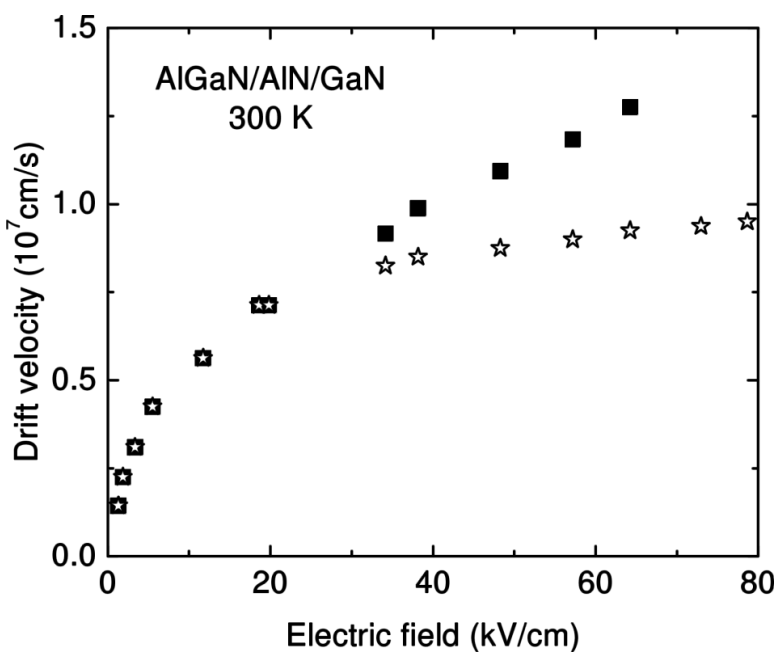

Fig. 3. Electron drift velocity in $\mathrm{AlGaN} / \mathrm{AlN} / \mathrm{GaN}$ channel (squares, present paper) and the result obtained under assumption of constant electron density (stars [17]).

When the electron sheet density is not constant, there is no proportionality between the current and the drift velocity. Therefore, the results on the electron drift velocity obtained under assumption of fieldindependent electron sheet density should be reconsidered. Squares in Fig. 3 present the result for the electron drift velocity after the correction for the hot electron capture. The correction exceeds $30 \%$ at $65 \mathrm{kV} / \mathrm{cm}$ electric field.

\section{Conclusion}

In undoped $\mathrm{AlGaN} / \mathrm{AlN} / \mathrm{GaN}$ channels, the electron density is found to depend on electric field applied in the plane of electron confinement. The measured dependence is used for correction of the electron drift velocity estimated when the electron capture has been ignored.

\section{Acknowledgements}

Partial support from the USA Office of Naval Research (ONR Grant N00014-03-1-0558 monitored by Dr Colin E.C. Wood) and the Lithuanian State Science and Studies Foundation (LVMSF Contracts T-24/05, C-33/2005) is gratefully acknowledged. Samples were grown and processed at Cornell University, Ithaca, 14853 NY, USA.

\section{References}

[1] L.F. Eastman, V. Tilak, V. Kaper, J. Smart, R. Thompson, B. Green, J.R. Shealy, and T. Prunty, Progress in high-power, high frequency AlGaN/GaN HEMTs, Phys. Status Solidi A 194(2), 433-438 (2002).

[2] U.K. Mishra, Gallium nitride electronics: Watt is the limit?, in: IEEE 62nd Device Research Conference Digest (Notre Dame, Indiana, USA, June 21-24, 2004) pp. 3-5.

[3] Y. Ando, Y. Okamoto, T. Nakayama, T. Inoue, K. Hataya, H. Miyamoto, M. Senda, K. Hirata, M. Kosaki, N. Shibata, and M. Kuzuhara, High power AlGaN / GaN heterojunction FETs for base station applications, in: IEEE 62nd Device Research Conference Digest (Notre Dame, Indiana, USA, June 21-24, 2004) p. 31 .

[4] L.F. Eastman, V. Tilak, J. Smart, B.M. Green, E.M. Chumbes, R. Dimitrov, H. Kim, O.S. Ambacher, N. Weimann, T. Prunty, M. Murphy, W.J. Schaff, and J.R. Shealy, Undoped AlGaN/GaN HEMTs for microwave power amplification, IEEE Trans. Electron Devices 48(3), 479-485 (2001).

[5] V. Kumar, W. Lu, R. Schwindt, A. Kuliev, G. Simin, J. Yang, M. Asif Khan, and I. Adesida, AlGaN/GaN HEMTs on SiC with $f_{T}$ of over $120 \mathrm{GHz}$, IEEE Electron Device Lett. 23(8), 455-457 (2002).

[6] A. Vertiatchikh, H. Kim, W.J. Schaff, L.F. Eastman, R. Thompson, V. Kaper, and R. Shealy, Bias dependent frequency response of AlGaN/GaN HEMT, in: Proceedings of the 27th Workshop on Compound Semiconductor Devices and Integrated Circuits held in Europe (Fürigen, Switzerland, 2003) pp. 41-42.

[7] C.H. Oxley and M.J. Uren, Measurements of unity gain cutoff frequency and saturation velocity of a $\mathrm{GaN}$ HEMT transistor, IEEE Trans. Electron Devices 52(2), 165-169 (2005).

[8] T.-H. Yu and K. Brennan, Monte Carlo calculation of two-dimensional electron dynamics in GaN-AlGaN heterostructures, J. Appl. Phys. 91(6), 3730-3736 (2002).

[9] M. Wraback, H. Shen, S. Rudin, E. Bellotti, M. Goano, J.C. Carrano, C.J. Collins, J.C. Campbell, and R.D. Dupuis, Direction-dependent band nonparabolicity effects on high-field transient electron transport in GaN, Appl. Phys. Lett. 82(21), 3674-3676 (2003).

[10] J.M. Barker, D.K. Ferry, S.M. Goodnick, D.D. Koleske, A.E. Wickenden, and R.L. Henry, Measurements of the velocity-field characteristic in AlGaN/GaN heterostructures, Microelectronics Eng. 63(1-3), 193-197 (2002).

[11] L. Ardaravičius, J. Liberis, A. Matulionis, L.F. Eastman, J.R. Shealy, and A. Vertiatchikh, Phys. Status Solidi A 201(2), 203-206 (2004).

[12] M. Ramonas, A. Matulionis, and L. Rota, Monte Carlo simulation of hot-phonon and degeneracy effects in the AlGaN/GaN two-dimensional electron gas channel, Semicond. Sci. Technol. 18(2), 118-123 (2003). 
[13] B.K. Ridley, W.J. Schaff, and L.F. Eastman, Hotphonon-induced velocity saturation in GaN, J. Appl. Phys. 96(3), 1499-1502 (2004).

[14] J.M. Barker, D.K. Ferry, S.M. Goodnick, D.D. Koleske, A. Allerman, and R.L. Shul, Effect of surface treatment on the velocity-field characteristics of $\mathrm{AlGaN} / \mathrm{GaN}$ heterostructures, Semicond. Sci. Technol. 19(4), S478-S480 (2004).

[15] L. Ardaravičius, A. Matulionis, J. Liberis, O. Kiprijanovič, M. Ramonas, L.F. Eastman, J.R. Shealy, and A. Vertiatchikh, Electron drift velocity in AlGaN/GaN channel at high electric fields, Appl. Phys. Lett. 83(19), 4038-4040 (2003).

[16] J.M. Barker, D.K. Ferry, S.M. Goodnick,
D.D. Koleske, A. Allerman, and R.L. Shul, High field transport in $\mathrm{GaN} / \mathrm{AlGaN}$ heterostructures, J. Vac. Sci. Technol. B 22(4), 2045-2050 (2004).

[17] L. Ardaravičius, M. Ramonas, O. Kiprijanovič, J. Liberis, A. Matulionis, L.F. Eastman, J.R. Shealy, $\mathrm{X}$. Chen, and Y. Sun, Comparative analysis of hot-electron transport in $\mathrm{AlGaN} / \mathrm{GaN}$ and $\mathrm{AlGaN} /$ AlN/GaN, Phys. Status Solidi A 200(5), 808-811 (2005).

[18] M. Ramonas, A. Matulionis, J. Liberis, L.F. Eastman, X. Chen, and Y.-J. Sun, Hot-phonon effect on power dissipation in a biased $\mathrm{Al}_{x} \mathrm{Ga}_{1-x} \mathrm{~N} / \mathrm{AlN} / \mathrm{GaN}$ channel, Phys. Rev. B 71(7), 075324-1-8 (2005).

\section{KARŠTŲJŲ ELEKTRONŲ PAGAVIMAS IR JU DREIFO GREIČIO MATAVIMAS AIGaN/ AIN / GaN}

O. Kiprijanovič, A. Matulionis, J. Liberis, L. Ardaravičius

Puslaidininkiu fizikos institutas, Vilnius, Lietuva

\section{Santrauka}

Nanosekundine impulsine technika, leidžiančia išvengti kvantinès protakos kaitimo, buvo matuojamas elektronu dreifo greitis ir elektronų tankio pokytis. Pastebèta, kad dèl karštųų elektronų pagavimo sumažėja judriụjų elektronų tankis. Sumažejimas pa- siekia net $30 \%$ kambario temperatūroje, kai lauko stipris artimas $65 \mathrm{kV} / \mathrm{cm}$. Kai laukai silpnesni už $25 \mathrm{kV} / \mathrm{cm}$, elektronų tankio kitimo nepastebèta. Pateikta pakoreguota, atsižvelgiant i elektronų tankio kitimą, elektronų dreifo greičio priklausomybė nuo elektrinio lauko stiprio. 